\title{
TITLE:
}

\section{Refractory cutaneous lichenoid sarcoidosis treated with tranilast.}

\section{$\operatorname{AUTHOR}(S)$ :}

Nakahigashi, Kyoko; Kabashima, Kenji; Akiyama, Hajime; Utani, Atsushi; Miyachi, Yoshiki

\section{CITATION:}

Nakahigashi, Kyoko ...[et al]. Refractory cutaneous lichenoid sarcoidosis treated with tranilast.. Journal of the American Academy of Dermatology 2010, 63(1): 171-172

\section{ISSUE DATE:}

2010-07

URL:

http://hdl.handle.net/2433/131868

\section{RIGHT:}

(C) 2010 Elsevier B.V.; This is not the published version. Please cite only the published version.; この論文は出版社版でありません。引用の際に は出版社版をご確認ご利用ください。 
Title:

A case of refractory cutaneous lichenoid sarcoidosis successfully treated with tranilast

Keywords: lichenoid sarcoidosis, sarcoidosis, granuloma annulare, tranilast,

\section{Authors:}

Kyoko Nakahigashi ${ }^{*}$ Kenji Kabashima ${ }^{*}$, Hajime Akiyama ${ }^{* *}$, Atsushi Utani ${ }^{*}$, Yoshiki Miyachi $^{*}$

* Department of Dermatology, Graduate School of Medicine, Kyoto University

** Department of Dermatology, Toyo-oka Public Hospital, Hyogo

Funding Sources: None.

Conflict of Interest Disclosure: None declared.

Manuscript word, table and figure count: 481 words, no table, 2 figures, and 4 references.

Correspondence should be addressed to Kyoko Nakahigashi, M.D.

Department of Dermatology, Graduate School of Medicine, Kyoto University,

54 Kawahara-cho, Sakyo-ku, Kyoto 606-8507, Japan.

Tel: 81-75-751-3310, Fax: 81-75-761-3002,

E-mail: nakahiga@kuhp.kyoto-u.ac.jp 
To the Editor: We would like to report a case of cutaneous lichenoid sarcoidosis, which was refractory to the conventional therapy but treated successfully with tranilast.

A 76-year-old Japanese man was referred to our clinic complaining of asymptomatic papules and erythematous plaques on his extremities and trunk (Fig. 1a-c). His health was good in general and he didn't take any oral medication. Superficial lymph nodes were not enlarged, and there was no abnormality on urinalysis, peripheral blood count or blood chemistry including blood sugar, hemoglobinA1c, angiotensin converting enzyme, and calcium. No abnormal finding was observed on chest radiography, chest and abdominal CT scans, electrocardiogram, and ophthalmologic examinations. QuantiFERON-TB Gold, an indirect diagnostic test for latent tuberculosis (TB) and active TB infections, was negative, either. The histology showed non-caseating necrotizing granulomatous infiltrates of epithelioid cells and giant cells throughout the upper to middle dermis. No atypical cell or histiocytic palisade surrounding mucin and degenerated collagen was found (Fig. 1d). Stains of Periodic acid-Schiff, Grocott methanamine silver, and Ziel-Nielson were all negative.

Based upon the clinical and histological findings above, the patient was diagnosed as cutaneous lichenoid sarcoidosis. Treatment with topical very strong class steroid ointment $(0.1 \%$ mometasone furoate) in accordance with psoralen-ultraviolet $\mathrm{A}$ 
(PUVA) were started, however, the eruptions were refractory to these therapies for over one year and extended progressively for the last several months. Since the manifestations were limited to the skin, oral administration of tranilast $300 \mathrm{mg} / \mathrm{day}$, instead of systemic steroid treatment, was initiated. In response to tranilast, the eruptions became smaller and subsided, leaving only pigmentation after the 5-month course of this therapy (Fig. 2a, b).

Initially, cutaneous sarcoidosis, generalized granuloma annulare (GA), or infectious granulomatous diseases was considered for differential diagnosis. Generalized GA is occasionally complicated with diabetes mellitus and often shows palisades of histiocytes surrounding prominent mucin histologically ${ }^{1,2}$, however, these findings were not seen in our case. Infectious granulomas were also excluded by a series of examinations on infection. Therefore, we diagnosed this case as the lichenoid type of cutaneous sarcoidosis. Topical corticosteroid can be effective to cutaneous sarcoidosis, but large or disfiguring lesions may require systemic corticosteroid therapy. Since sarcoidosis can relapse after cessation of steroid treatment ${ }^{3}$, indications for systemic corticosteroids should be limited to the patients with vital organ involvements. In our case, the skin eruptions, refractory to topical steroids and PUVA therapy, were attenuated by the treatment with tranilast. Tranilast, N-3,4-dimethoxycinnamoyl 
antheranilic acid, is an anti-allergic drug used for the treatment of atopic dermatitis or keloid since 1980s. The precise underlying mechanism is unknown, but it has been demonstrated that tranilast inhibited the release of chemical mediators and the multinucleated giant cell formation of monocytes in vitro. ${ }^{4}$ There has been no report of diffusely-scattered lichenoid sarcoidosis treated successfully with tranilast. Although limited to a single case, it is considered that tranilast can be a choice for cutaneous lichenoid sarcoidosis refractory to conventional regimen. 


\section{References}

1 Dabski K, Winkelmann RK. Generalized granuloma annulare: clinical and laboratory findings in 100 patients. J Am Acad Dermatol 1989; 20: 39-47.

2 Dabski K, Winkelmann RK. Generalized granuloma annulare: histopathology and immunopathology. Systematic review of 100 cases and comparison with localized granuloma annulare. J Am Acad Dermatol 1989; 20: 28-39.

3 English JC, 3rd, Patel PJ, Greer KE. Sarcoidosis. J Am Acad Dermatol 2001; 44: 725-43; quiz 44-6.

4 Mizuno $\mathrm{K}$, Okamoto $\mathrm{H}$, Horio $\mathrm{T}$. Inhibitory influences of tranilast on multinucleated giant cell formation from monocytes by supernatant of concanavalin A-stimulated mononuclear cells. J Dermatol Sci 2000; 24: 166-70. 


\section{Figure legends}

Fig 1. Clinical manifestations and histology. (a) Erythematous plaques and maculopapules were seen over the whole body (explanatoy; the darky-red lesion $\left(^{*}\right)$ is hemangioma simplex). (b) Individual lesions were 3- to 5-mm in a diameter, pinkish, follicular papules on the abdomen. (c) The clusters of the papules looked like erythematous plaques on the upper extremity. (d) Histological examination showed a dermal granulomatous infiltrate of epithelioid cells without caseating necrosis. A few giant cells and a sparce infiltration of lymphocytes were noted. (hematoxylin and eosin staining; magnification 200×.)

Fig 2. Clinical findings after oral tranilast therapy. After the treatment with tranilast, the skin lesions on the abdomen (a) and on the upper extremity (b) were attenuated. 
(a)

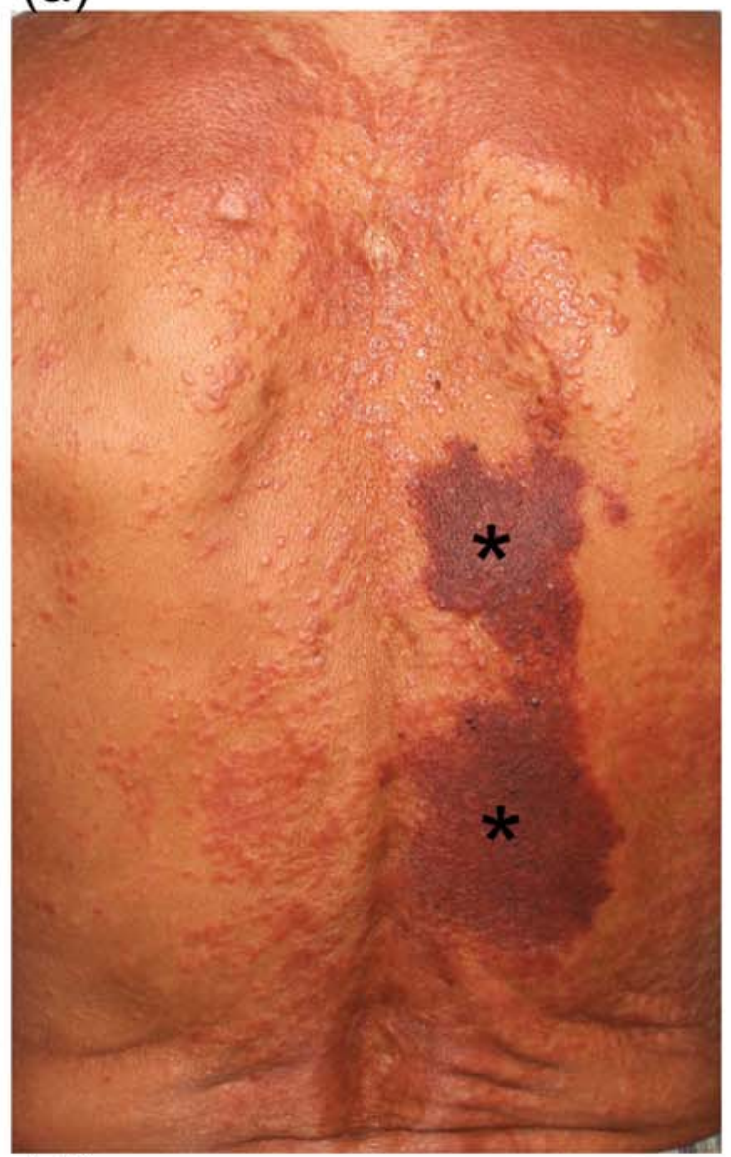

(b)

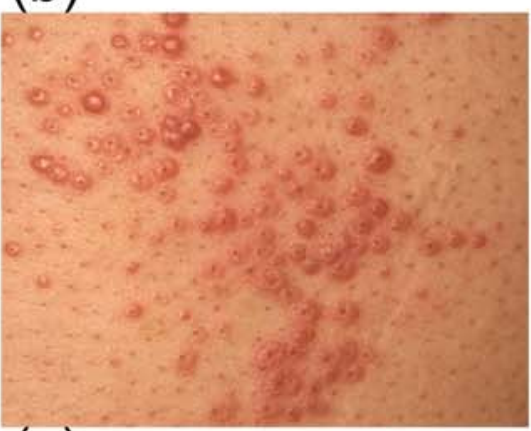

(c)

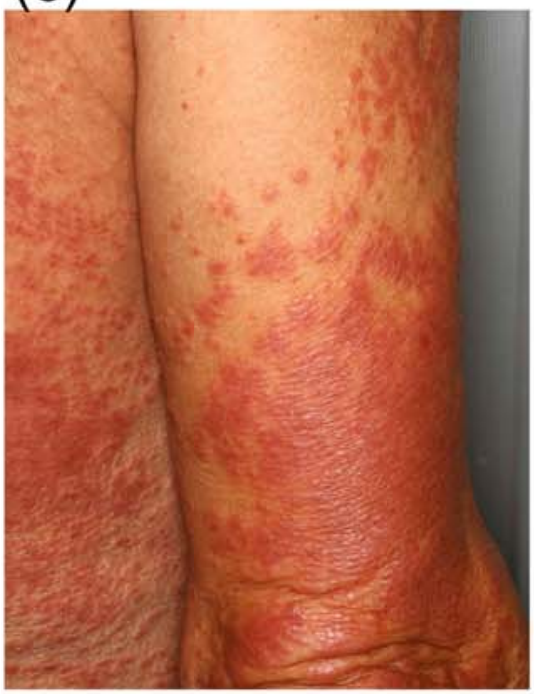

(d)

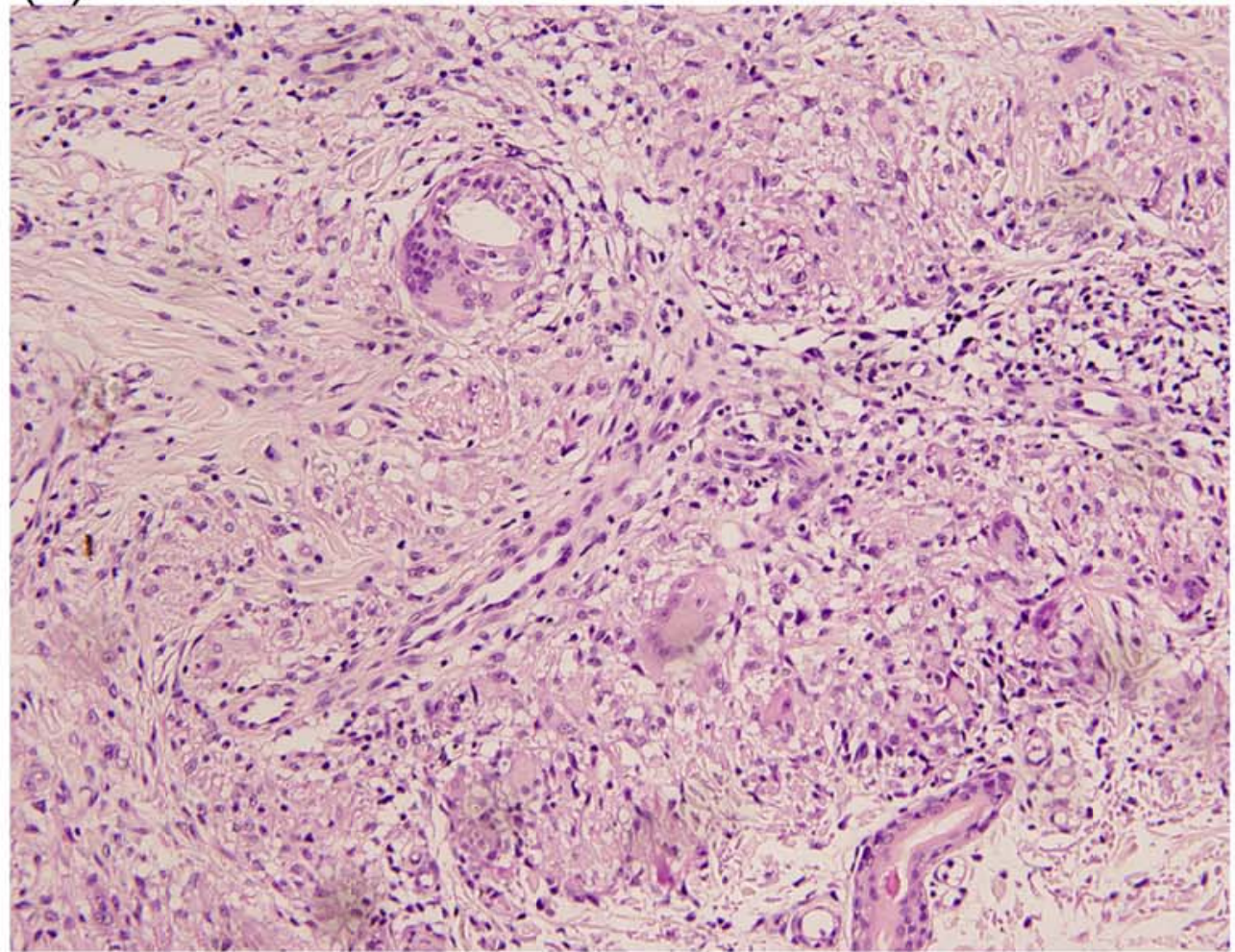

Fig. 1 
(a)

(b)

Fig. 2 